\title{
An Overview of Profile of Entrepreneurs and Enterprises In India
}

\author{
S. Aswini Priya, Ch. Vinoda Rao, Pulidindi Venugopal
}

\begin{abstract}
Performance of any enterprise depends among other things, on the nature of its organization, educational qualifications and experience of the persons running them, soundness of the business idea as originally conceived, seriousness of the entrepreneur to succeed in the chosen business activity, work done from the stage of conception to commissioning and so on. This study profiles the SSEs in Andhra Pradesh and also that of the entrepreneurs. The Government of India, since then have chosen the path of encouraging them by making available necessary inputs for their survival and growth and at the same time emphasizing the need for modernization and up-gradation of technologies to improve their competitive strength, giving of course good bye to the protectionist policies followed till 1990.
\end{abstract}

Keywords: Andhra Pradesh, competitive strength, enterprise, modernization.

\section{INTRODUCTION}

During the post liberalization period (after 1990), SSEs faced a difficult situation of having to compete with large sized enterprises situated in India and abroad, as the gates were opened to foreign enterprises to sell their products in India. Keeping in view the importance of the SSI sector in the Indian economy, the Government of India made considerable efforts to promote their growth during the successive Five Year Plan periods. The strategy for their development comprises of formulation and pursuit of deliberate policies for their protection and development, stepping up of plan allocations, creation of a plethora of supporting institutions, implementation of various programmes, provision of industrial finance on concessional terms and granting of financial and tax incentives. These measures resulted in rapid growth of SSEs in the country.

The number of registered SSEs increased from 16,000 as at the end of March, 1950 to 36,000 by 1961, 8.53 lakhs by 1986 and to 21.96 lakhs by $1992 .{ }^{10}$ Data relating to Micro and Small Enterprises (MSEs) as they are now called, in terms of number of units, production, employment and exports as at the end of March 1997 to 2007 are presented in Table-1. It can be observed from the table that their number increased from 28.03 lakhs in 1997 to 34.60 lakhs by 2002 and 39.87 lakhs by 2007. Employment provided by them during the

Revised Manuscript Received on September 16, 2019.

* Correspondence Author

S. Aswini priya, VIT Business School, Vellore Institute of Technology, Vellore, India. Email: priyapri.254@gmail.com

Dr. Ch. Vinoda Rao*, Department of Business Administration, K.G.R.L College of PG courses, Bhimavaram, India. Email: vinod.jaavi@gmail.com

Dr. Pulidindi Venugopal, Department of Technology Management, Vellore Institute of Technology, Vellore, India. Email: pulidindi.venu@vit.ac.in

(c) The Authors. Published by Blue Eyes Intelligence Engineering and Sciences Publication (BEIESP). This is an open access article under the CC BY-NC-ND license (http://creativecommons.org/licenses/by-nc-nd/4.0/) same period increased from 16 millions in 1997 to 18.75 millions by 2002 and further to 19.97 millions by 2007 . Value of their output increased from Rs.4, 11,858 crores in 1997 to Rs.6, 85,397 crores in 2002 and further to Rs.8, and 62,591 crores in 2007. Value of exports of SSEs increased from Rs.39, 248 crores in 1997 to Rs.62, 376 crores in 2002 and further to Rs.69, 616 crores in 2007.

During the period under review, the years 1998 to 2001 stand out with a perceptible increase in the number of units, value of production and exports. Though the increase in the value of production and exports is caused to some extent by the inflationary factor, the average growth rate achieved by the SSEs is significantly higher (10.90 per cent) than that achieved by the Large Scale Sector" (5.20 per cent).

Table 1: SSEs in India at a glance as at the end of March, 1997 to 2007 in terms of select indicators

\begin{tabular}{|c|c|c|c|c|c|c|}
\hline \multirow{2}{*}{ FY } & \multirow{2}{*}{$\begin{array}{l}\text { NO. } \\
\text { (in } \\
\text { Lakh } \\
\text { s) }\end{array}$} & \multirow{2}{*}{$\begin{array}{c}\text { PCP } \\
\text { (Rs. In } \\
\text { Crores) }\end{array}$} & \multirow{2}{*}{$\begin{array}{c}\text { EMP } \\
\text { (in } \\
\text { Lakhs) }\end{array}$} & \multirow{2}{*}{$\begin{array}{c}\text { ECP } \\
\text { (Rs. In } \\
\text { Crores) }\end{array}$} & \multicolumn{2}{|c|}{ Growth Rate } \\
\hline & & & & & $\begin{array}{c}\text { SSE } \\
\text { Sector }\end{array}$ & $\begin{array}{c}\text { LSE } \\
\text { Sector }\end{array}$ \\
\hline $1996-97$ & $\begin{array}{l}28.03 \\
(4.78) \\
\end{array}$ & $\begin{array}{c}4,11,858 \\
(6.87) \\
\end{array}$ & $\begin{array}{c}160.00 \\
(4.84) \\
\end{array}$ & $\begin{array}{l}39,248 \\
(12.27) \\
\end{array}$ & 11.30 & 5.6 \\
\hline 1997-98 & $\begin{array}{l}29.44 \\
(5.03)\end{array}$ & $\begin{array}{c}4,62,641 \\
(12.33)\end{array}$ & $\begin{array}{l}167.20 \\
(4.50)\end{array}$ & $\begin{array}{l}44,442 \\
(13.23)\end{array}$ & 8.43 & 6.7 \\
\hline 1998-99 & $\begin{array}{l}30.80 \\
(4.85) \\
\end{array}$ & $\begin{array}{c}5,20,650 \\
(12.54) \\
\end{array}$ & $\begin{array}{c}171.58 \\
(2.62) \\
\end{array}$ & $\begin{array}{l}48,979 \\
(10.21) \\
\end{array}$ & 7.70 & 4.1 \\
\hline 1999-00 & $\begin{array}{l}32.12 \\
(4.28)\end{array}$ & $\begin{array}{c}5,72,887 \\
(10.23)\end{array}$ & $\begin{array}{c}178.50 \\
(2.33)\end{array}$ & $\begin{array}{l}54,200 \\
(10.66)\end{array}$ & 8.16 & 6.5 \\
\hline 2000-01 & $\begin{array}{l}33.70 \\
(4.92)\end{array}$ & $\begin{array}{c}6,45,496 \\
(12.67)\end{array}$ & $\begin{array}{l}185.64 \\
(4.00)\end{array}$ & $\begin{array}{c}59,978 \\
(9.63)\end{array}$ & 8.09 & 4.9 \\
\hline 2001-02 & $\begin{array}{l}34.60 \\
(2.67)\end{array}$ & $\begin{array}{c}6,85,397 \\
(6.18)\end{array}$ & $\begin{array}{l}187.52 \\
(1.02)\end{array}$ & $\begin{array}{c}62,376 \\
(3.99)\end{array}$ & 4.00 & 5.1 \\
\hline 2002-03 & $\begin{array}{l}35.64 \\
(3.00)\end{array}$ & $\begin{array}{c}7,18,425 \\
(4.81)\end{array}$ & $\begin{array}{l}193.48 \\
(3.18)\end{array}$ & $\begin{array}{c}63,412 \\
(1.66)\end{array}$ & 1.66 & 5.2 \\
\hline 2003-04 & $\begin{array}{l}36.43 \\
(2.22) \\
\end{array}$ & $\begin{array}{c}7,52,391 \\
(4.72) \\
\end{array}$ & $\begin{array}{c}195.26 \\
(0.92) \\
\end{array}$ & $\begin{array}{c}65,318 \\
(3.01) \\
\end{array}$ & 3.00 & 5.7 \\
\hline 2004-05 & $\begin{array}{l}37.52 \\
(2.99)\end{array}$ & $\begin{array}{c}7,83,592 \\
(4.15) \\
\end{array}$ & $\begin{array}{c}196.38 \\
(0.57)\end{array}$ & $\begin{array}{c}66,423 \\
(1.69) \\
\end{array}$ & 1.69 & 5.9 \\
\hline 2005-06 & $\begin{array}{l}37.84 \\
(0.85) \\
\end{array}$ & $\begin{array}{c}8,19,765 \\
(4.62) \\
\end{array}$ & $\begin{array}{c}199.35 \\
(1.51) \\
\end{array}$ & $\begin{array}{r}68,527 \\
(3.17) \\
\end{array}$ & 3.17 & 6.2 \\
\hline 2006-07 & $\begin{array}{l}39.87 \\
(5.36) \\
\end{array}$ & $\begin{array}{c}8,62,591 \\
(5.24) \\
\end{array}$ & $\begin{array}{c}199.75 \\
(0.20) \\
\end{array}$ & $\begin{array}{c}69,616 \\
(1.59) \\
\end{array}$ & 1.59 & 6.7 \\
\hline
\end{tabular}

Note: FY-Financial Year, No-Number, PCP-Production at Current Prices, EMP-Employment, ECP-Exports at Current Prices

Figures in brackets below the absolute numbers indicate growth rates over the immediately preceding year.

Source:

1) Compiled from Hand Book of Industrial Statistics for the relevant years.

2) Development Commissionerate of Micro Small and Medium Enterprises (MSMEs), Government of India, New Delhi. 


\section{An Overview of Profile of Entrepreneurs and Enterprises In India}

\section{PROFILE OF ENTREPRENEURS AND ENTERPRISES}

In this section it is proposed to examine aspects of this kind with a comparative eye in relation to both Healthy and Sick SSEs in Andhra Pradesh which are specifically chosen for the study with a view to provide necessary backdrop for a meaningful evaluation of their performance.

\section{A. Type of Organization}

Data relating to the composition of the SSEs in Andhra Pradesh in regard to type of organization are presented in Table-2.

It may be observed from the table that in the proprietary concerns category, 84 per cent are healthy and 62 per cent are sick. Like-wise 17.00 per cent in Public Limited Companies category and 14 per cent in partnership concerns category are found to be sick. Interaction with the entrepreneurs indicates that high incidence of sickness in the case of partnerships concerns category is an account of disputes among the partners, while similar situation observed in the case of Public Limited Companies category is due to sudden decline in demand for products in the market and disputes among joint owners. But in the case of sole proprietary concerns, sickness is traced to inability of the entrepreneurs to cope up with fast changing demands.

Table 2: Classification of Number of SSEs in Andhra Pradesh based on type of organization as at the end of March, 2007

\begin{tabular}{|c|c|c|}
\hline \multirow{2}{*}{ Type of organization } & \multicolumn{2}{|c|}{ Number of Enterprises } \\
\cline { 2 - 3 } & Healthy & Sick \\
\hline Sole Proprietory Concerns & $84(84.00)$ & $62(62.00)$ \\
\hline Joint Hindu Family Concerns & $2(2.00)$ & 6 \\
\hline Partnership Concerns & $9(9.00)$ & $14(14.00)$ \\
\hline Cooperatives & $1(1.00)$ & $3(3.00)$ \\
\hline Private Limited Companies & $3(3.00)$ & $4(4.00)$ \\
\hline Public Limited Companies & $1(1.00)$ & $17(17.00)$ \\
\hline Total & 100 & 100 \\
\hline
\end{tabular}

Figures in Brackets indicate percentage

It shows that market situation caused by fall in demand for the products and rise in interest burden on one hand and the inability to update production technology at appropriate time on the other. It is pertinent to note that almost 40 per cent of the entrepreneurs running their enterprises which are sick are either unaware of the financial facilities made available for technology up-gradation or lacked proper access to funds from financial institutions exactly at the time needed. So there is need to educate entrepreneurs about the facilities kept ready to benefit them in regard to making funds available for up-gradation of technology and even timely meeting of working capital requirements caused by sudden setbacks in their liquidity situation. It is however clear that type of organization per se has little to do with the health or otherwise of the SSEs under study.

\section{B. Socio-Economic Status}

Socio-economic background of the entrepreneurs in terms of level of their education, financial status, previous experience etc., generally influences the performance of enterprises. Hence, an attempt is made to examine these variables of the entrepreneurs running the SSEs. Data relating to educational background of the entrepreneurs of the SSEs are presented in Table-3.

It may be observed from the table that both healthy and sick enterprises consist of entrepreneurs with different levels of education. Incentives given by the Government, the problem of unemployment after completing education in their chosen field, encouragement from family members are relatives, a strong desire to succeed in business and amassing wealth are stated to be the reasons for starting the SSEs. However, a comparison of educational levels of entrepreneurs in healthy and sick enterprises reveals that 44 per cent of healthy enterprises and 37 per cent of sick enterprises have entrepreneurs with technical qualifications ranging from ITI diploma to Post Graduate level degrees.

Table 3: Level of education of the entrepreneurs of Healthy and Sick SSEs in Andhra Pradesh

\begin{tabular}{|c|c|c|}
\hline \multirow{2}{*}{ Level of education } & \multicolumn{2}{|c|}{ Number of Enterprises } \\
\cline { 2 - 3 } & Healthy & Sick \\
\hline Non-Matriculates & $2(2.00)$ & $6(6.00)$ \\
\hline Intermediate & $12(12.00)$ & $28(28.00)$ \\
\hline $\begin{array}{c}\text { Bachelor's Degree } \\
\text { (Non-Technical) }\end{array}$ & $32(32.00)$ & $22(22.00)$ \\
\hline Bachelor's Degree (Technical) & $28(28.00)$ & $18(18.00)$ \\
\hline ITI/Diploma in Engineering & $12(12.00)$ & $16(16.00)$ \\
\hline $\begin{array}{c}\text { Post Graduate Degree } \\
\text { (Non-Technical) }\end{array}$ & $8(8.00)$ & $7(7.00)$ \\
\hline $\begin{array}{c}\text { Post Graduate (Technical) } \\
\text { Other Professional }\end{array}$ & $4(4.00)$ & $0(3.00)$ \\
\hline $\begin{array}{c}\text { Degrees/Diplomas such as } \\
\text { Chartered Accountancy, etc. }\end{array}$ & $2(2.00)$ & 100 \\
\hline Total & 100 & $0.00)$ \\
\hline
\end{tabular}

Figures in Brackets indicate percentage

Like-wise, 64 per cent of healthy enterprises and 63 per cent of sick enterprises have entrepreneurs with non-technical qualifications of whom 34 in the case of sick enterprises and 14 in the case of healthy enterprises have education up to Intermediate level only. The above data cannot suggest that low levels of education are responsible for sickness or otherwise of the SSEs, but suggest that enterprises run by entrepreneurs with higher levels of education, particularly with technical background are relatively doing better. Hence, it appears that educational level of entrepreneurs could at the most be reckoned as one of the factors influencing the success or otherwise of the enterprises, but not the only factor.

Data relating to work experience of entrepreneurs of SSEs presented in Table-4 indicate that in the case of healthy enterprises 86 per cent have entrepreneurs with previous work experience and 14 per cent had no such experience, while in the case of sick enterprises 68 per cent have previous work experience and 32 per cent did not have such experience.. It therefore appears that enterprises run by entrepreneurs with work experience are somewhat more successful than those run by entrepreneurs without such work experience.

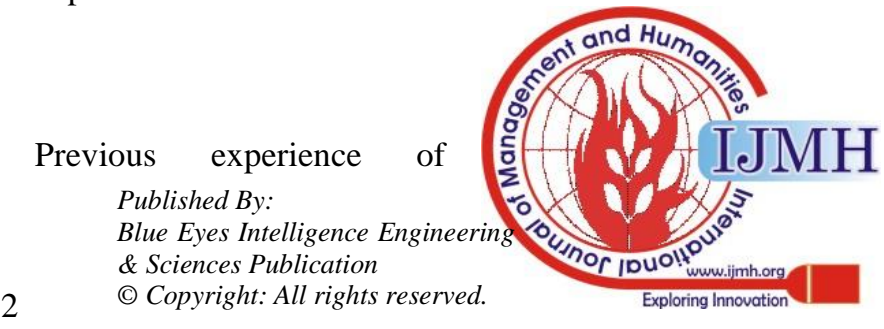


entrepreneurs could be one of the important factors but not the only factor leading to success or otherwise of the enterprises. However, since previous work experience in similar organizations or enterprises engaged in similar line of activity is more likely to contribute to success, data relating to nature of work experience of entrepreneurs of both healthy and sick enterprises are gathered. The same are presented in Table-5.

Table 4: Work experience of entrepreneurs in Healthy and Sick SSEs in Andhra Pradesh

\begin{tabular}{|c|c|c|}
\hline \multirow{2}{*}{} & \multicolumn{2}{|c|}{ Number of Enterprises } \\
\cline { 2 - 3 } & Healthy & Sick \\
\hline With Work Experience & $86(86.00)$ & $68(68.00)$ \\
\hline Without Work Experience & $14(14.00)$ & $32(32.00)$ \\
\hline Total & 100 & 100 \\
\hline
\end{tabular}

Figures in Brackets indicate percentage

Table 5: Nature of work experience of entrepreneurs of Healthy and Sick SSEs in Andhra Pradesh

\begin{tabular}{|c|c|c|}
\hline \multirow{2}{*}{} & \multicolumn{2}{|c|}{ Number of Enterprises } \\
\cline { 2 - 3 } & Healthy & Sick \\
\hline $\begin{array}{c}\text { Employee in Similar } \\
\text { Organization }\end{array}$ & $62(72.10)$ & $18(26.48)$ \\
\hline Employee in Other Organizations & $16(18.60)$ & $26(38.23)$ \\
\hline Proprietor/Partner in Business & $5(5.82)$ & $20(29.41)$ \\
\hline Government Employees & $2(2.32)$ & $1(1.47)$ \\
\hline Any Other & $1(1.16)$ & $3(4.41)$ \\
\hline Total & $86(100.00)$ & $68(100.00)$ \\
\hline
\end{tabular}

Fig. in Brackets indicate percentage

It may be observed from the table that of the 86 entrepreneurs of healthy enterprises with previous experience, 72.10 per cent had experience in similar organizations, and 18.60 per cent had experience in organizations engaged in other lines of business. Similarly, of the 68 entrepreneurs of sick enterprises with previous experience, 26.48 per cent had experience in similar organizations, whereas 38.23 per cent had experience in organisations engaged in other lines of business activity. It could be further observed from the table that the percentage of entrepreneurs with previous experience in Government service or other services has been very low being less than five percent in the case of both healthy and sick SSEs. The available data neither confirm nor reject the view that previous work experience is a major determinant in the success or otherwise of such enterprises.

Factors behind commencement of business as mentioned by the entrepreneurs of healthy and sick SSEs are shown in Table-6. Inability to secure jobs, incentives given by the Government, encouragement given by friends and relatives, financial soundness coupled with self-confidence are stated to be the reasons for establishing SSEs. It can be observed from the table that 14 per cent of healthy and 32 per cent of sick enterprises mention that lack of jobs drew them into business. Further 26 per cent of healthy enterprises and 22 per cent of sick enterprises, report that they started their enterprises due to the incentives given by the Government. It can also be observed that 20 per cent of healthy enterprises report that encouragement given by friends and relatives is a major reason, while only three per cent of sick enterprises cite this reason for coming into business. Similarly, while only 12 per cent of healthy enterprises came into being due to availability of capital and other resources, the percentage is far higher being 27 in the case of sick enterprises.

Table 6: Reasons for commencement of SSEs in Andhra Pradesh

\begin{tabular}{|c|c|c|}
\hline \multirow{2}{*}{} & \multicolumn{2}{|c|}{ Number of Enterprises } \\
\cline { 2 - 3 } & Healthy & Sick \\
\hline Lack of job & 14 & 32 \\
\hline Incentives given by Government & 26 & 22 \\
\hline Encouragement from friends and relatives & 20 & 03 \\
\hline Self-Confidence & 28 & 16 \\
\hline Availability of Capital and their resources & 12 & 27 \\
\hline Total & 100 & 100 \\
\hline
\end{tabular}

It is also noticed that 20 per cent of the entrepreneurs who commenced SSEs are first generation entrepreneurs, some of whom met with success, while others could not, and had suffered losses. This underlines the need for educating neophyte entrepreneurs about preparation of feasibility studies both technical and financial, before commencing business. In the course of interaction with the entrepreneurs, it has come to the knowledge that many enterprises have fallen sick due to badly conceived ideas, and sudden changes in technology and markets. In this context, a careful examination as to the source of business idea becomes relevant. Data relating to source of business idea in the case of both healthy and sick SSEs are presented in Table-7.

It can be observed from the table that DICs have been a major source of business idea to both healthy and sick enterprises followed by other promotional corporations. Commercial Banks were a source of business idea but to a limited number of enterprises. It is also noticed that 13 per cent of the sick and five percent of healthy SSEs mention that they got the business idea from their own personal experience. It is strange to find that 68 per cent of healthy enterprises got the business idea from DICs while 66 per cent of enterprises, which also got the business idea from the same DICs have eventually fallen sick. This drove the researcher for further investigation which revealed that the individual decisions of the entrepreneurs led to sickness of their enterprises and there was nothing wanting from the side of DICs.

Table 7: Classification of Entrepreneurs of SSEs in Andhra Pradesh on the basis of source of business idea

\begin{tabular}{|c|c|c|}
\hline \multirow{2}{*}{ Source of Business Idea } & \multicolumn{2}{|c|}{ Number of Enterprises } \\
\cline { 2 - 3 } & Healthy & Sick \\
\hline Friends and Relatives & 6 & 4 \\
\hline Personal Work Experience & 5 & 13 \\
\hline District Industries Centres & 68 & 66 \\
\hline Commercial Banks & 5 & 1 \\
\hline Other Promotional Corporations & 16 & 16 \\
\hline Total & 100 & 100 \\
\hline
\end{tabular}

Success or otherwise of an enterprise depends, among other things on the soundness of the business idea. It is quite probable that even if the idea is good, it may be badly translated into action due to thoughtless decisions of the entrepreneurs or sudden changes in other environmental factors. 


\section{An Overview of Profile of Entrepreneurs and Enterprises In India}

However, if the idea itself is unsound and taken in a hasty manner, the enterprises cannot survive for long even when right direction and leadership is provided by the entrepreneur. Hence the agency that is involved in evolving and suggesting the business idea also plays a considerable role in the success or otherwise of an enterprise, generally ideas conceived by Government agencies and professional firms and individual entrepreneurs possessing professional qualifications and skill with good exposure to market conditions, would be, by and large, good and enterprises coming into existence based on ideas coming from such agencies would be generally successful. Hence, data relating to SSEs classified on the basis of agencies involved in the preparation of feasibility report are gathered and presented in Table-8.

It can be observed from the table that a majority (58 per cent) of healthy enterprises got the feasibility reports prepared by professional firms followed by those which got them prepared by Government agencies. (28 per cent). In the case of sick enterprises dependence on Government agencies and professional firms is more or less same, but as many as 27 prepared them on their own and it is noticed in the course of interaction with the entrepreneurs that 18 of them had no professional qualifications or experience. It is suggested that promotional corporations and all funding agencies and Government educate prospective entrepreneurs about the need for getting feasibility reports prepared by Government agencies or professional firms.

Table 8: Classification of SSEs in Andhra Pradesh on the basis of agency depended upon for preparation of feasibility reports

\begin{tabular}{|c|c|c|}
\hline \multirow{2}{*}{ Agency } & \multicolumn{2}{|c|}{ Number of Enterprises } \\
\cline { 2 - 3 } & Healthy & Sick \\
\hline Government Agency & $28(28.00)$ & $32(32.00)$ \\
\hline Professional firms & $58(58.00)$ & $31(31.00)$ \\
\hline Bankers & $2(2.00)$ & $4(4.00)$ \\
\hline Themselves & $8(8.00)$ & $27(27.00)$ \\
\hline Friends and relatives & $4(4.00)$ & $6(6.00)$ \\
\hline Total & $100(100.00)$ & $\begin{array}{c}100 \\
(100.00)\end{array}$ \\
\hline
\end{tabular}

Figures in Brackets indicate percentage

Registration of SSEs is not compulsory. It is voluntary. However registered enterprises get some advantages in the matter of securing term finance, obtaining scarce raw-materials and sale of finished products. So, most of the SSEs try to get themselves registered. Registration is done in two stages viz., temporary and permanent. While temporary registration is not stated to be difficult, SSEs are facing some problems in obtaining permanent registration. The problems faced in registration by the SSEs are shown in Table-9.

It can be observed from the table that delay is a major problem faced by 58 per cent of healthy and 42 per cent of sick enterprises. Indifference of staff of Industries Department is cited as a problem by 24 per cent of healthy and 33 per cent of sick enterprises. While 12 per cent of healthy and 18 per cent of sick enterprises complain of cumbersomeness procedural formalities, very limited number viz., six per cent of healthy and seven per cent of sick enterprises inform that they had to make unofficial payments to speed up the process of registration. Interaction with the entrepreneurs reveals that the delay was mostly on account of delay in obtaining clearances from Municipalities, Pollution Control Boards and from local authorities under local regulations.Caste of entrepreneurs per se has little to do with the performance of their enterprises. However, entrepreneurs' caste background determines cultural background of entrepreneurs which could affect performance of enterprises. Generally enterprises run by Scheduled Caste of entrepreneurs per se have little to do with the performance of their enterprises. However, entrepreneurs' caste background determines cultural background of entrepreneurs which could affect performance of enterprises. Generally enterprises run by Scheduled Caste and Scheduled Tribes would be less successful than those run by entrepreneurs belonging to other castes, due to low level of education, lack of previous exposure and experience, inferiority complex, fear of approaching high level officials and so on. Hence, there could be an indirect and distant relationship between caste of the entrepreneurs and performance of their enterprises. Data relating to caste composition of the entrepreneurs of SSEs are presented in Table-10.

Table 9: Problems faced in Registration by the SSEs in Andhra Pradesh

\begin{tabular}{|c|c|c|}
\hline \multirow{2}{*}{ Type of Problem } & \multicolumn{2}{|c|}{ Number of Enterprises } \\
\cline { 2 - 3 } & Healthy & Sick \\
\hline Procedural Formalities & $12(12.00)$ & $18(18.00)$ \\
\hline Delays & $58(58.00)$ & $42(42.00)$ \\
\hline Indifference of Staff & $24(24.00)$ & $33(33.00)$ \\
\hline Need for making unofficial payments & $6(6.00)$ & $7(7.00)$ \\
\hline Total & $100(100.00)$ & $\begin{array}{c}100 \\
(100.00)\end{array}$ \\
\hline
\end{tabular}

Figures in Brackets indicate percentage

It can be observed from the table that of the enterprises surveyed, three per cent of healthy and four percent of sick belong to Scheduled Castes (SC) and like-wise one per cent of healthy and two per cent of sick belong to Scheduled Tribe (ST). In other words, participation of entrepreneurs belonging lower social strata has been very limited despite all the steps being taken to encourage SC \& ST entrepreneurs. It could also be observed that there is a predominance of entrepreneurs belonging to other castes (forward castes) and other backward classes who constitute 96 per cent of healthy and 94 per cent of sick enterprises.

It is needless to point out that the economic background of entrepreneurs also affects the performance of enterprises. Entrepreneurs hailing from affluent and educated families obviously possess greater amount of knowledge, skill and risk-bearing capacity as compared to those hailing from poor and uneducated families. Hence, an attempt is made to examine the economic background of the entrepreneurs of SSEs. The relevant data are shown in Table-11.
Blue Eyes Intelligence Engineering \& Sciences Publication (C) Copyright: All rights reserved. 
Table 10: Caste composition of Entrepreneurs of SSEs in Andhra Pradesh

\begin{tabular}{|c|c|c|}
\hline \multirow{2}{*}{ Caste } & \multicolumn{2}{|c|}{ Number of Enterprises } \\
\cline { 2 - 3 } & Healthy & Sick \\
\hline Scheduled castes & $3(3.00)$ & $4(4.00)$ \\
\hline Scheduled tribes & $1(1.00)$ & $2(2.00)$ \\
\hline Backward classes & $37(37.00)$ & $43(43.00)$ \\
\hline Other castes & $59(59.00)$ & $51(51.00)$ \\
\hline Total & $100(100.00)$ & $\begin{array}{c}100 \\
(100.00)\end{array}$ \\
\hline
\end{tabular}

Figures in Brackets indicate percentage

Table 11: Economic background of Entrepreneurs of SSEs in Andhra Pradesh

\begin{tabular}{|c|c|c|}
\hline \multirow{2}{*}{ Background } & \multicolumn{2}{|c|}{ Number of Enterprises } \\
\cline { 2 - 3 } & Healthy & Sick \\
\hline First generation entrepreneurs & $38(38.00)$ & $32(32.00)$ \\
\hline Business legacy from parents & $48(48.00)$ & $54(54.00)$ \\
\hline Financially sound parents & $8(8.00)$ & $6(6.00)$ \\
\hline Poor financial status of parents & $6(6.00)$ & $8(8.00)$ \\
\hline Total & $\begin{array}{c}100 \\
(100.00)\end{array}$ & $\begin{array}{c}100 \\
(100.00)\end{array}$ \\
\hline
\end{tabular}

Figures in Brackets indicate percentage

It may be observed from the table that 38 per cent of healthy and 32 per cent of sick enterprises are run by first generation entrepreneurs. Asked about the reason for coming into business, they inform that they took to business due to their self-confidence and the desire to avail themselves of business opportunities opening up in the economy. A majority i.e., 48 per cent of healthy and 54 per cent of sick enterprises have been just continuing the business started by their parents or just diversified into new lines of activity. However, those running the sick enterprises hastened to add that they would liquidate the existing ones and start new ventures. It is also observed that less than 10 per cent of the entrepreneurs only are from financially sound families. At the same time, it is interesting to note that six per cent of healthy and eight per cent of sick enterprises are started by entrepreneurs hailing from poor family background. Thus the available data do not confirm or reject the view that economic background of the entrepreneurs would influence the performance of SSEs. This calls for more exclusive micro level studies to examine the link between economic background and performance of SSEs.

\section{CONCLUSION}

Composition of SSEs in Andhra Pradesh in regard to type of organization reveals that sole proprietary concerns account for a major share of 91.14 per cent in healthy and 55.15 per cent of sick enterprises. Partnership concerns account for 4.10 per cent in the case of healthy and 25.23 per cent in sick enterprises. It is observed that sickness in partnership and Joint Hindu Family concerns is on account of disputes among partners or co-partners while in the case of Limited Companies, it is mostly on account of market factors. 40 per cent of the entrepreneurs are found to be unaware of financial facilities made available for technology up-gradation or lacked proper access to fund purveying institutions. This underlines the need for educating the entrepreneurs about the facilities made available by the Government for technology up-gradation and rehabilitation packages.

Educational background of the entrepreneurs of healthy and sick SSEs in Andhra Pradesh reveals that educational level has little to do with health or sickness, but appeared to be one of the many factors influencing it. 86 per cent of entrepreneurs of healthy and 68 per cent of sick enterprises had previous work experience while others did not have such experience. Though no direct link could be established between possession of previous work experience and success or otherwise of enterprises, success rate was relatively higher in those run by entrepreneurs with previous work experience.

An analysis of the factors behind commencement of SSEs in Andhra Pradesh reveals that 20 per cent of the entrepreneurs happen to be first generation entrepreneurs who floated the enterprises due to various reasons. They came to the field without adequate training/exposure or preparatory work resulting in sickness in their enterprises. This underlines the need for giving entrepreneurial development programmes to prospective entrepreneurs about the problems and prospects of starting the enterprise and about how to handle finances, sales, production, etc. In addition, the fund providing institutions have to monitor the progress of newly started SSEs and help them in times of need to facilitate their healthy growth.

Just as we cannot get a clear print from a blurred negative, so also, we cannot get a successful enterprise if the very business idea conceived is unsound. Due to ill-conceived business idea, many enterprises have fallen sick. An examination of the source of business idea in Andhra Pradesh reveals that 68 per cent of healthy enterprises got the business idea from DICs, but 66 per cent of sick enterprises which also got the business idea from the DICs have eventually fallen sick. Further analysis of this strange situation indicated that there was nothing wrong with the functioning of the DICs as such, but the enterprises have fallen sick due to the inappropriate decisions of the entrepreneurs., This calls for continuous monitoring of the working of the enterprises by the DICs and also term lending institutions to ensure that entrepreneurs are guided properly to take appropriate decisions based on rational analysis of the situation after weighing the pros and cons of alternative courses of action to avoid sickness and contribute to their healthy growth.

58 per cent of healthy and 42 per cent of sick SSEs in Andhra Pradesh experienced delays in getting themselves registered. Indifference of staff and maze of procedural formalities are cited as major difficulties in securing registration. Hence, there is need to simplify the procedural formalities and to open a separate desk for taking up registration work and complete all formalities at one place adopting single window system and also to introduce a system of feedback from entrepreneurs for quickly redressing their complaints.

Participation of Scheduled Caste and Scheduled Tribes in the floatation of SSEs in Andhra Pradesh has been considerably low. 
Of the enterprises surveyed, three per cent of healthy and three per cent of sick are run by Scheduled Castes and likewise one per cent of healthy and two per cent of sick enterprises belong to Scheduled Tribe. It is thus evident that various steps taken by the Government for promotion of entrepreneurs belonging to these lower strata of the society have not made much headway. This underlines the need to identify prospective entrepreneurs belonging to Scheduled Caste and Scheduled Tribe Categories and to encourage them from conception to commissioning and monitor their enterprises closely till they stabilize and prosper.

A close look at the financial background of the families of entrepreneurs belonging to healthy and sick enterprises neither confirms nor rejects the view that economic background is a decisive factor in determining success or otherwise of an enterprise, as some started by financially sound entrepreneurs have fallen sick, while some started by those with poor financial status, have been successful. It, therefore appears that more exclusive micro level studies are required to examine the link between financial background of the entrepreneurs and success or otherwise of the enterprises.

\section{REFERENCES}

1. Economic Survey, 1992-93.

\section{AUTHORS PROFILE}

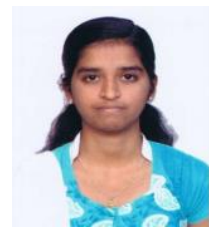

S. Aswini Priya, Research Associate VIT Business School Vellore Institute of Technology Vellore-632014. priyapri.254@gmail.com

S. Aswini Priya is a Research Associate in VIT Business School, VIT. She pursued Integrated MBA in VIT Business School and started to pursue her doctorate in 2015. She worked as Project Associate in ICSSR funded project for two years and published 10 research papers in top reputed journals and 3 book chapters till 2019.
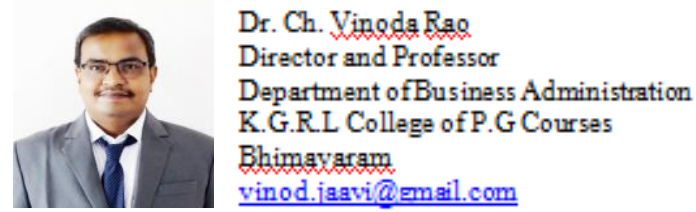

Dr. Ch. Vinoda Rao is a Professor and Head of the Department has Teaching Experience of 21 years and specialized in the area of Finance. He obtained his masters degree in Business Administration from Andhra University in the year of 1998. He has qualified State Level Eligibility Test (SLET) conducted by APPSC Hyderabad in the year of 1999. In his academic excellence has published 5 national and one international journal with ISSN and wrote one book with ISBN and also participated and presented 16 National seminars and conferences. He has guided more than 375 MBA projects.

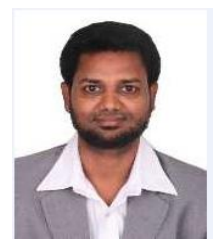

Dr. Pulidindi Venugopal, Professor Department of Technology Management School of Mechanical Engineering Vellore Institute of Technology Vellore-632014. pulidindi.venu@vit.ac.in

Dr. Pulidindi Venugopal is an enthusiastic marketing professor and a researcher. He started his teaching profession at VIT in 2009. He published 63 research articles in top rated journals, Case studies in top rated case centers and 'holds more than 15 Book chapters till 2019. He also produced 7 doctorates till date and holds two funded research projects given by Indian Council of Social Science and Research (ICSSR). 